\title{
Biosaintifika
}

Journal of Biology \& Biology Education

http://journal.unnes.ac.id/nju/index.php/biosaintifika

\section{Relationship between Zingiberaceae Leaves Compounds and its Tyrosinase Activity}

\author{
${ }^{\circledR}$ Irmanida Batubara $^{1,2}$, Yuni Kartika ${ }^{1}$, Latifah K Darusman ${ }^{1,2}$
}

DOI: 10.15294/biosaintifika.v8i3.6742

${ }^{1}$ Department of Chemistry, Faculty of Mathematics and Natural Sciences, Bogor Agricultural University, Indonesia

${ }^{2}$ Tropical Biopharmaca Research Center, Bogor Agricultural University, Indonesia

\section{History Article}

Received 9 August 2016 Approved 7 November 2016 Published 24 December 2016

\section{Keywords:}

pigment content; tannin content; tyrosinase inhibition; Zingiberaceae leaves

\begin{abstract}
The leaves of Zingiberaceae family has not been much explored its potential, especially as a skin lightening. The relationship between total anthocyanins, chlorophyll, carotenoids and tannins contents of Zingiberaceae leaves and tyrosinase activity were determined. Ten species of Zingiberaceae were separated by $n$-hexane and the residues were extracted with ethyl acetate. The total anthocyanins, chlorophyll, carotenoids, tannins contents and the activities of ethyl acetate extracts were determined by spectrometric method. The tyrosinase inhibition was determined by using L-tyrosine (monophenolase) and L-DOPA (diphenolase) substrates. The most active extract was the leaves extract of Zingiber purpureum which exhibited $82.86 \%$ for monophenolase inhibition and the leaves extract of Curcuma zedoaria which exhibited $90.20 \%$ for diphenolase inhibition. The correlation between carotenoids content and monophenolase inhibition was $52 \%$, while between tannin content and diphenolase inhibition was only $15 \%$. Therefore, among 10 leaves species of Zingiberaceae, Zingiber purpureum Roscoe and Curcuma zedoaria leaves are the most potential for tyrosinase inhibitors and can be developed as whitening agent.
\end{abstract}

\section{How to Cite}

Batubara, I., Kartika, Y. \& Darusman, L. K. (2016). Relationship between Zingiberaceae Leaves Compounds and its Tyrosinase Activity. Biosaintifika: Journal of Biology \& Biology Education, 8(3), 370-376.

(C) 2016 Universitas Negeri Semarang

\footnotetext{
$\triangle$ Correspondence Author:

Campus IPB Darmaga, Bogor, 16680 Indonesia

E-mail: ime@apps.ipb.ac.id
}

p-ISSN 2085-191X e-ISSN 2338-7610 


\section{INTRODUCTION}

Skin lightening agent is a substance that could reduce the color intensity of human skin. One way to lighten the skin is by using cosmetic promoting the peeling of stratum corneum from the epidermis. If the peeling does not take place, dead cells will make the skin dull, rough and dirty, wide-pores will form and skin pigment will pile-up. Another way to lighten the skin is by inhibiting the enzymatic process. Tyrosinase is an enzyme involved in pigmentation process, in which process, known as monophenolase reaction, tyrosinase catalizes tyrosine into 3,4dihydroxyphenylalanine (DOPA). DOPA is then oxidized into dopaquinone, by tyrosinase known as diphenolase reaction, which is subsequently promote a reaction producing eumelanin and feomelanin pigments (Likhitwitayawuid, 2008).

These enzymatic inhibitory compounds may be extracted from Zingiberaceae, which is known to have many species and may grow well in Indonesia. Curcuma xanthorrhiza from Indonesia is one example which is then widely spread to other countries (Batubara et al., 2015). Furthermore, there are many reports on the antioxidant potentials and some other activities of the rhizomes of Zingiberaceae (Sabli et al., 2012). Determination of the potential as tyrosinase inhibitor related to the pigment, such as anthocyanins, chlorophyll and carotenoids, as well as the tannins contents is very important since every herbal medicine has distinct pharmacological effects and very unique properties (Mahendra, 2006). Therefore, it was conducted determination on the relationship between the activity of tyrosinase inhibition and the pigment and tannins contents of 10 species of Zingiberaceae leaves by quantifying the content of anthocyanins, chlorophyll, carotenoids, and tannins. Polyphenol compounds like tannins, chlorophyll, and anthocyanins have the capability as antioxidants, the compounds that scavenge free radicals. At the same time, some antioxidants are known to have the activities as tyrosinase inhibitors (Batubara et al., 2010).

The rhizomes of Zingiberaceae are used as the main materials in jamu preparation (Irawan et al., 2013; Shanthi et al., 2014). The leaves part, however, is still insufficiently used. Leaves are the part of a plant where photosynthesis occurs. The products of photosynthesis will be then distributed to all parts of the plant. To grow, the leaves need nutrients from the soil that will be provided and delivered by the roots. In this relation, therefore, there are several chemical substances that will be distributed to all parts of a plant, and this make the leaves possible to be used as a new natural source for skin lightening agent. Some research related to Zingiberaceae leaves had been conducted such as Zingiberaceae leaves essential oils as antimicrobe and biofilm degradation (Batubara et al., 2016), and Zingiberaceae leaves as antioxidant and antiaging agent (Zahra et al., 2016), while the potency of Zingiberaceae leaves as tyrosinase inhibitor had not been developed yet. In addition to the potency as skin whitening, the correlation the compounds from Zingiberaceae leaves and the activity also need to be understand. In this study, the contents of anthocyanins, chlorophyll, carotenoids, and tannins were determined by using spectrometric method and the tyrosinase inhibition activity was determined to all extracts. Additionally, it was also determined the group of the active compounds and the species of the leaves that work as and potential to be tyrosinase inhibitor. This research results will give the information about the active leaves to inhibit tyrosinase and its compound groups that responsible to the activity.

\section{METHODS}

Tyrosinase inhibition and antioxidant activities of the leaves of 10 Zingiberaceae species were analyzed in several stages: sample collection and preparation, sample extraction by maceration, determination of anthocyanins, chlorophyll, carotenoids, and tannins contents, and tyrosinase inhibition activity assay. The research was conducted from January till August 2016 at Analytical Chemistry Laboratory, Department of Chemistry, Faculty of Mathematics and Natural Sciences and laboratory of Tropical Biopharmaca Research Center, Bogor Agricultural University, Bogor Indonesia.

The apparatus used in this study are, among others, micro-plate reader, oven, furnace, and other glass equipment. The materials used are, among others, leaves from 10 species of Zingiberaceae: Curcuma aeruginosa Roxb., Zingiber officinale Roscoe, Boesenbergia rotunda (L.) Mansf., Elettaria cardamomum (L.) Maton Syn.Amonum cardamomum L., Zingiber montamum (J.könig) Link ex A. Dietr. Syn.Zingiber zerumbet (L.) Roscoe ex Sm., Zingiber purpureum Roscoe, Curcuma longa L., Alpinia galanga (L.) Willd., Curcuma xanthorrhiza Roxb., Curcuma zedoaria (Christm.) Roscoe syn. Curcuma pallida Lour. (Heyne), $n$-hexane, ethyl acetate, ethanol, acetone, quercetin as standard, kojic acid as standard, conc. $\mathrm{HCl}$, vanillin, Tris buffer $\mathrm{pH} 7.8, \mathrm{AlCl}_{3} 10 \%, 1 \mathrm{M} \mathrm{CH}_{3} \mathrm{COONa}$, phosphate buffer $\mathrm{pH} 6.5$, DMSO (dimethyl sul- 
foxide), tyrosinase enzyme, L-tyrosine, L-DOPA, and other chemicals.

The leaves of Zingiberaceae were collected from the conservation and cultivation unit of Tropical Biopharmaca Research Center, IPB, Cikabayan, Dramaga, Bogor. The plants collected were determined the species in Research Center for Biology Indonesian Institute of Sciences, Cibinong, Bogor. The identification results are shown in Table 1 . The leaves were sliced and dried at $40^{\circ} \mathrm{C}$. The dried leaves were grounded and filtered using 60 mesh-sized filter.

The method of extraction used was graded maceration. About $250 \mathrm{~mL} n$-hexane was added to $50 \mathrm{~g}$ of leaves powder to remove the non-polar part, the fat-free leaves powder was then extracted by using ethyl acetate as solvent.

Extract solution $100 \mathrm{mg} / \mathrm{L}$ was made with methanol : $\mathrm{HCl}$ : water $(90: 1: 1)$ as solvent, the solution was shaken, and the absorbance were measured at $650 \mathrm{~nm}$ and $529 \mathrm{~nm}$. Anthocyanins content was reported in $\% \mathrm{w} / \mathrm{w}(\mathrm{g} / \mathrm{g})$ of extract.

Extract solution $100 \mathrm{mg} / \mathrm{L}$ was made with acetone:Tris buffer $\mathrm{pH} 7.8$ (8:2) as solvent, the solution was shaken, and the absorbances were measured at $470 \mathrm{~nm}, 537 \mathrm{~nm}, 647 \mathrm{~nm}$, and 663 nm. Chlorophyll and carotenoids contents were reported in \%w/w (mg/g) of extract.

About $125 \mu \mathrm{L}$ extract solution was mixed with $250 \mu \mathrm{L} 4 \%$ vanillin in ethanol and $125 \mu \mathrm{L}$ conc. $\mathrm{HCl}$ was then added to the mixture. The mixture was incubated at room temperature for 30 minutes. Subsequently, $250 \mu \mathrm{L}$ mixture was added to the wells of a 96-well plate and the absorbances were then measured at $500 \mathrm{~nm}$. Cathechin was used as standard. Tannin content was reported in $\% \mathrm{w} / \mathrm{w}(\mathrm{g} / \mathrm{g})$ of extract.

The extract was dissolved in DMSO and then diluted with $50 \mathrm{mM}$ phosphate buffer $(\mathrm{pH}$ 6.5) to $250 \mathrm{mg} / \mathrm{L}$. Further, $70 \mu \mathrm{L}$ of the extract solution was added to the wells of a 96-well plate. $30 \mu \mathrm{L}$ Tyrosinase (Sigma, $333 \mathrm{Unit}^{-1} \mathrm{~mL}^{-1}$ in phosphate buffer) was added and the mixture was incubated for 5 minutes. The mixture was further added with $110 \mu \mathrm{L}$ substrate ( $2 \mathrm{mM}$ L-tyrosin or $12 \mathrm{mM}$ L-DOPA) and incubated at $37^{\circ} \mathrm{C}$ for 30 minutes. The absorbances were measured at 492 $\mathrm{nm}$. Kojic acid was used as a positive control.

\section{RESULTS AND DISCUSSION}

Maceration was used in the extraction of active substances of the leaves samples for its simple procedure and, additionally, heat destruction of the heat-sensitive components may be minimized despite of much solvent needed and little yield obtained. In order to prevent destruction of the already extracted substances, the extracts were concentrated by using rotary evaporator at a relatively low temperature of about $40^{\circ} \mathrm{C}$. The measurement of pigments and flavonoid contents as well as the tyrosinase inhibition activity was performed to all obtained extracts. Table 2 shows the results of the measurements.

The ethyl acetate extract yields of different types of leaves, both from the same and different genus, are different. This study used leaves from the genus of Alpinia, Bosenbergia, Curcuma, Elettaria, dan Zingiber. The highest yield was obtained from Zingiber officinale dan Elettaria cardamomum, while Boesenbergia rotunda gave the least yield. High yield will increase the opportunity of the relevant leave to be developed into product.

The anthocyanins contents of the extracts were very variable, from Zingiber officinale and Elettaria cardamomum leaves extracts of about 0.8

Table 1. Scientific and local name of 10 zingiberaceae species on this study

\begin{tabular}{ll}
\hline Scientific Name & Local Name \\
\hline Alpinia galangal (L.) & Lengkuas \\
Boesenbergia rotunda (L.) Mansf. & Temu kunci \\
Curcuma aeruginosa Roxb. & Temu hitam \\
Curcuma longa L. & Kunyit \\
Curcuma xanthorrhiza Roxb & Temu lawak \\
Curcuma zedoaria (Christm.) Roscoe syn. & Temu putih \\
Curcuma pallida Lour. (Heyne) & \\
Elettaria cardamomum (L.) Maton Syn. Amonum cardamomum L. & Kapulaga \\
Zingiber montamum (J. könig) Link ex A. Dietr. Syn. & Lempuyang \\
Zingiber zerumbet (L.) Roscoe ex Sm. & \\
Zingiber officinale Roscoe & Jahe Merah \\
Zingiber purpureum Roscoe & Bangle Hantu \\
\hline
\end{tabular}


Table 2. Extract yield, pigment and flavonoid contents of Zingiberaceae leaves

\begin{tabular}{lccccc}
\hline Scientific Name & Yield & \multicolumn{5}{c}{ Content (\%) } \\
\cline { 3 - 6 } & $(\%)$ & Anthocyanins & Chlorophyll & Carotenoids & Tannins \\
\hline Alpinia galangal (L.) & $1.92^{\mathrm{e}}$ & $2.73^{\mathrm{a}}$ & $0.55^{\mathrm{a}}$ & $0.49^{\mathrm{c}}$ & $10.06^{\mathrm{b}}$ \\
Boesenbergia rotunda (L.) Mansf. & $1.36^{\mathrm{g}}$ & $2.15^{\mathrm{b}}$ & $0.56^{\mathrm{a}}$ & $0.53^{\mathrm{b}}$ & $9.84^{\mathrm{b}}$ \\
Curcuma aeruginosa Roxb. & $2.78^{\mathrm{c}}$ & $1.65^{\mathrm{d}}$ & $0.28^{\mathrm{c}}$ & $0.18^{\mathrm{f}}$ & $8.96^{\mathrm{c}}$ \\
Curcuma longa L. & $1.89^{\mathrm{e}}$ & $1.54^{\mathrm{d}}$ & $0.32^{\mathrm{bc}}$ & $0.28^{\mathrm{d}}$ & $9.49^{\mathrm{bc}}$ \\
Curcuma xanthorrhiza Roxb & $2.92^{\mathrm{b}}$ & $1.92^{\mathrm{c}}$ & $0.39^{\mathrm{b}}$ & $0.28^{\mathrm{d}}$ & $7.91^{\mathrm{d}}$ \\
Curcuma zedoaria (Christm.) Roscoe & $2.38^{\mathrm{d}}$ & $1.91^{\mathrm{c}}$ & $0.22^{\mathrm{d}}$ & $0.18^{\mathrm{f}}$ & $10.22^{\mathrm{b}}$ \\
Elettaria cardamomum (L.) Maton & $3.40^{\mathrm{a}}$ & $0.95^{\mathrm{f}}$ & $0.17^{\mathrm{e}}$ & $0.09^{\mathrm{h}}$ & $11.60^{\mathrm{a}}$ \\
Zingiber montamum (J. könig) Link & $2.03^{\mathrm{e}}$ & $1.15^{\mathrm{e}}$ & $0.26^{\mathrm{cd}}$ & $0.24^{\mathrm{e}}$ & $8.87^{\mathrm{c}}$ \\
ex A. Dietr. & & & & & \\
Zingiber officinale Roscoe & $3.34^{\mathrm{a}}$ & $0.84^{\mathrm{f}}$ & $0.20^{\mathrm{d}}$ & $0.15^{\mathrm{g}}$ & $5.40^{\mathrm{e}}$ \\
Zingiber purpureum Roscoe & $1.71^{\mathrm{f}}$ & $1.59^{\mathrm{d}}$ & $0.54^{\mathrm{a}}$ & $0.55^{\mathrm{a}}$ & $7.15^{\mathrm{d}}$ \\
\hline Dang
\end{tabular}

Data followed by the same letter are not significantly different according to Duncan's multiple comparison test $\mathrm{P}=0.01$

$-0.9 \%(\mathrm{w} / \mathrm{w})$ to Zingiber montamum leave extract of $2.73 \%(w / w)$. According to Sims and Gamon (2002) leaves contain about $3 \%$ anthocyanins. If the anthocyanins content of the extracts of this study are converted into anthocyanins content in the leaves, the anthocyanins content in the leaves of Zingiberaceae will only between about 0.03 $0.05 \%$. This is because not all the anthocyanins were extracted into the ethyl acetate, but some anthocyanins left unextracted in the residual leaves. Anthocyanins, in leaves, are found in the mesophyll and inner epidermis, which content is higher in young leaves due to lower photosynthesis rate. In leaves, anthocyanins are red pigments that can absorb excess of light or UV light, anthocyanins, moreover, is believed to scavenge radicals (Radovanovic \& Radovanovic, 2010; Miguel, 2011). Anthocyanins in the samples of the present study are expected to be used as tyrosinase inhibitor because it is likely that the anthocyanins have the same functional groups with L-tyrosine or L-DOPA.

Chlorophyll in leaves is consisted of chlorophyll a and chlorophyll $b$, which differ in the substituent groups of the porphyrin ring and the wavelength used to measure. Based on the structure, chlorophyll is neither too polar nor nonpolar. Total chlorophyll content analysis to 10 leaves species of Zingiberaceae gave various results, from $0.17 \%$ to $0.56 \%$. In leaves, chlorophyll is photosynthetic pigments used to absorb the sunlight.

In leaves, there are two classes of carotenoids, carotenes (carotenoids consisting of only carbon and hydrogen atoms) and xanthophylls (carotenoids consisting of carbon, hydrogen, and oxygen atoms). Based on the structure, which is mostly hydrocarbon, carotenoids extracted more to $n$-hexane and ethyl acetic (Kljak \& Grbeša, 2015). In this study, the leaves are first separated with $n$-hexane, which makes the carotenoids content in the ethyl acetate extracts decreases if compared to the leaves directly extracted with ethyl acetate. Carotenoids contents of 10 leaves species of Zingiberaceae of this study are vary widely. The highest carotenoids content is from the leaves extract of Zingiber purpureum and the lowest is from the leaves extract of Elettaria cardamomum. The proportion of the carotenoids and chlorophyll contents of Zingiberaceae leaves ranges from 1:10 to 1:5. In leaves, carotenoids are yellow pigments that may be used to absorb excess energy from the sun. Based on the structure, carotenoids have a large number of conjugated double bonds that they may be used to scavenge free radicals (Charlotte et al., 2015).

Tannins are polyphenols acting as secondary metabolites. Tannins are consisted of condensed tannins and hydrolized tannins. Condensed tannins are formed from the condensation of flavanol, commonly known as proanthocyanidins. Condensed tannins content is determined by vanillin- $\mathrm{HCl}$ method. The basic principle of this method: vanillins are protonated in acid, carbocations are then formed and react with flavanoids. The resulting intermediary compounds undergo dehydration and produce red color. Condensed tannins have the properties as antioxidant and reduce the risk of cancer. The capacity of tannins bioactivity depends largely on the structure and the degree of polymerisation. Different plant species has different structure and content. 


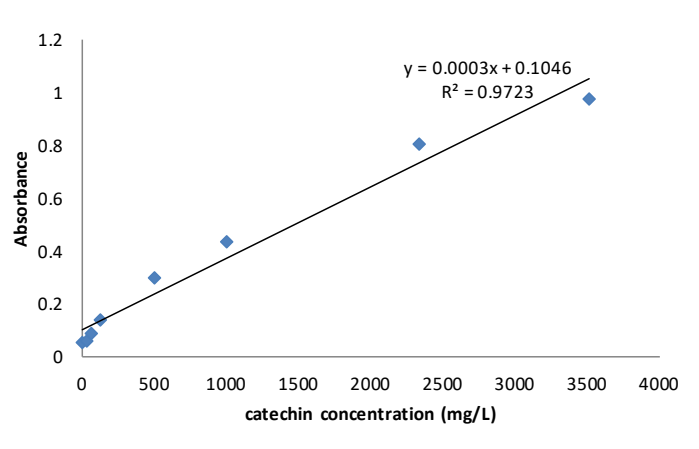

Figure 1. Catechin standard curve in tannins content determination

The calculation of tannins content in the samples used a line equation of catechin standard series (Figure 1). The results for 10 leaves spesies of Zingiberaceae vary widely from $5.40 \%$ in the leaves extract of Zingiber officinale Roscoe to $11.60 \%$ in the leaves extract of Elettaria cardamomum. The presence of condensed tannins in all extracts suggests that all extracts have the activity as tyrosinase inhibitors.

Pigmentation may be reduced by inhibiting the activity of tyrosinase, which may be performed, among others, by using secondary metabolites present in plants. One compound that is commonly used to inhibit the activity of tyrosinase is kojic acid.

Determination on the extracts capability to be tyrosinase inhibitors used 2 substrates with extract concentration of $250 \mathrm{mg} / \mathrm{L}$. The crude extracts of 10 leaves species of Zingiberaceae gave various results both in the reactions of monophenolase and dipehenolase inhibitions (Table 3). Generally, the inhibition activities of the extracts were higher in monophenolase than in dipheno- lase. The highest monophenolase inhibition activity was found in the leaves extract of Zingiber purpureum with result that was not significantly different with kojic acid as positive control. For diphenolase, the highest inhibition was found in the leaves extract of Curcuma zedoaria with activity better than the posivite control. At the same time, the leaves extracts of Zingiber officinale and Zingiber montamum gave the lowest results and showed poor activities in inhibiting both monophenolase and diphenolase. This difference in activities is considered due to the difference in the level of active compounds and also in the types of compounds contained in a particular species that it is believed there is one particular compound affecting the activity more in respective extracts.

The essential oil of Zingiber purpureum reported had activity to inhibit the Streptococcus aureus growth with MIC of $2 \mathrm{mg} / \mathrm{mL}$, while the essential oil of Zingiber officinale did not inhibit the same microbe growth (Batubara et al., 2016). This result indicated that Zingiber purpureum leaves could be use as antimicrobe as well as whitening agent.

The relationship between monophenolase and diphenolase inhibitions and pigment and tannins contents was determined in this study. The two parameters were directly proportional, which means the higher the pigment or tannins contents, the higher the activity. Monophenolase inhibition activity correlates to carotenoids content, with 0.5302 correlation, and to chlorophyll content, with 0.5261 correlation (Figure 2), while other levels of carotenoids and chlorophyll had correlation of not less than 0.3 that it may be suggested there was no correlation with mono-

Table 3. Tyrosinase inhibition activity of ethyl acetate extracts of Zingiberaceae leaves

\begin{tabular}{lcc}
\hline Scientific name & \multicolumn{2}{c}{ Inhibition Activity (\%) } \\
\cline { 2 - 3 } & monophenolase & diphenolase \\
\hline Alpinia galangal (L.) & $55.84^{\mathrm{c}}$ & $12.88^{\mathrm{g}}$ \\
Boesenbergia rotunda (L.) Mansf. & $67.79^{\mathrm{b}}$ & $38.13^{\mathrm{cd}}$ \\
Curcuma aeruginosa Roxb. & $41.41^{\mathrm{e}}$ & $16.34^{\mathrm{f}}$ \\
Curcuma longa L. & $41.30^{\mathrm{e}}$ & $31.00^{\mathrm{d}}$ \\
Curcuma xanthorrhiza Roxb & $37.72^{\mathrm{f}}$ & $22.24^{\mathrm{e}}$ \\
Curcuma zedoaria (Christm.) Roscoe & $46.60^{\mathrm{d}}$ & $90.20^{\mathrm{a}}$ \\
Elettaria cardamomum (L.) Maton & $46.53^{\mathrm{d}}$ & $41.53^{\mathrm{c}}$ \\
Zingiber montamum (J. könig) Link ex A. Dietr. & $12.80^{\mathrm{g}}$ & $10.96^{\mathrm{g}}$ \\
Zingiber officinale Roscoe & $15.71^{\mathrm{g}}$ & $12.14^{\mathrm{g}}$ \\
Zingiber purpureum Roscoe & $82.86^{\mathrm{a}}$ & $41.78^{\mathrm{c}}$ \\
Kojic acid (positive control) & $85.57^{\mathrm{a}}$ & $67.68^{\mathrm{b}}$ \\
\hline
\end{tabular}


phenolase inhibition activity. This correlation suggested that the Zingiberaceae leaves with high carotenoids and chlorophyll content could be developed as skin whitening agent by inhibition of monophenolase.

Positive correlation between diphenolase activity and pigment content was not found. The highest value of 0.1513 correlation was only found with tannins content. Therefore, it may be concluded that tyrosinase activity, especially diphenolase, was not affected by pigment and tannins but by other secondary metabolites content, such as flavonoid. Batubara and Adfa (2013) reported that quercetin could have a role in the tyrosinase inhibition. It is interesting to find the correlation between total flavonoid content with diphenolase inhibition activity.

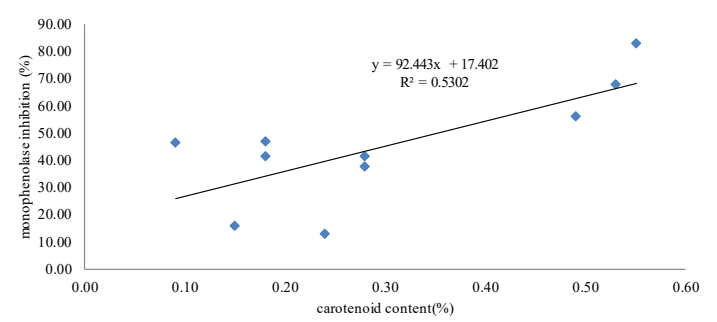

(a)

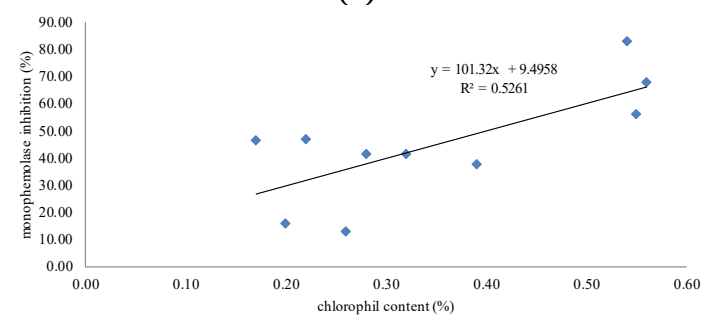

(b)

Figure 2. Correlation between carotenoid content (a) and chorophyll content (b) and monophenolase activity

\section{CONCLUSION}

Tyrosinase-inhibition activity, especially monophenolase inhibition, correlates with pigment and carotenoid contents, although the correlation is only about $50 \%$. On the contrary, diphenolase inhibition activity does not have any linear correlation with pigment and tannins contents. The activity is expected from other secondary metabolites such as phenolic compounds or other secondary metabolites. Among 10 Zingiberaceae leaves, the leaves of Curcuma zedoaria (Christm.) Roescoe and Zingiber purpureum Roscoe need to be further analyzed for active compounds responsible for the tyrosinase inhibition activity.

\section{REFERENCES}

Batubara, I., Darusman, L. K., Mitsunaga, T., Rahminiwati, M., \& Djauhari, E. (2010). Potency of Indonesian Medicinal Plants as Tyrosinase Inhibitor and Antioxidant Agent. Journal of Biological Science, 10(2), 138-144

Batubara, I., \& Adfa, M. (2013). Potensi daun kayu bawang (Protium javanicum) sebagai penghambat kerja enzim tirosinase. Jurnal Sains dan Matematika, 1(2), 52-56.

Batubara, I., Julita, I., Darusman, L. K., Mudathir, A. M., \& Mitsunaga, T. (2015). Flower Bracts of Temulawak (Curcuma xanthorrhiza) for skin care: Anti-Acne and Whitening Agent. Procedia Chemistry, 14, 216-224

Batubara, I., Wahyuni, W. T., \& Susanto, M. (2016) Antibacterial Activity of Zingiberaceae Leaves Essential Oils Against Streptococcus mutans and Teeth Biofilm Degradation. International Journal of Pharma and Bio Science, 7(4), 111-116

Charlotte, Sy, Olivier, D., Patrick, B., Catherine, C. (2015). Interactions between carotenoids from marine bacteria and other micronutrients: impact on stability and antioxidant activity. Mar Drugs, 13(11), 7020-7039.

Formagio, A. S. N., Volobuff, C. R. F., Santiago, M., Cardoso, C. A. L., Vieira, M. D. C., \& Pereira, Z. V. (2014). Evaluation of antioxidant activity, total flavonoids, tannins and phenolic compounds in Psychotria leaf extracts. Antioxidants. 3(40), 745-757.

Irawan, Y. R., Fitmawati, \& Herman, (2013). Pengetahuan Tumbuhan Obat Dukun Sakai Desa Sebangar Duri Tiga Belas dan Desa Kesumbo Ampai Duri Kabupaten Bengkalis. Biosantifika: Journal of Biology \& Biology Education, 5(1), 3035

Kljak, K., \& Grbeša, D., (2015). Carotenoid content and antioxidant activity of hexane extracts from selected Croatian corn hybrids. Food Chem 167, 402-408

Likhitwitayawuid, K. (2008). Stilbenes with tyrosinase inhibitory activity. Current Sci, 94(1),44-52.

Mahendra, B. (2006). Panduan Meracik Herbal. Jakarta: Penebar Swadaya.

Miguel, M.G. (2011). Anthocyanins: antioxidant and/ or anti-inflammatory activities. $J$ Appl Pharmac Sci. 1(6), 7-15.

Radovanovic, B., \& Radovanovic, A. (2010). Free radical scavenging activity and anthocyanin profile of carbenet sauvignon wines from the balkan region. Molecules. 15(6), 4213-4226.

Sabli, F., Mohamed, M., Rahmat, A., Ibrahim, H., \& Bakar, M.F.A. (2012). Antioxidant properties of selected Etlingera and Zingiber species (Zingiberaceae) from Borneo Island. J Biol Chem. 6(1), 1-9.

Shanthi, R. V., Jumari, \&Izzati, M. (2014). Studi Etnobotani Pengobatan Tradisional untuk Perawatan Wanita di Masyarakat Keraton Surakarta Hadiningrat. Biosaintifika: Journal of 
Irmanida Batubara et al,. / Biosaintifika 8 (3) (2016) 370-376

Biology \& Biology Education. 6(2), 61-69

Sims, D. A., \& Gamon, J. A. (2002). Relationships between leaf pigment content and spectral reflectance across a wide range of species, leaf structures and developmental stages. Remote sensing of environment, 81(2), 337-354.

Zahra, U., Kartika, Y., Batubara, I., Darusman, L.K., Maddu, A. (2016). Screening the potency of Zingiberaceae leaves as antioxidant and antiaging agent. Nusantara Bioscience. 8(2), 221-225 